\title{
The effects of ethinylestradiol and progestins ("the pill") on cognitive function in pre-menopausal women
}

\author{
Andrea Gogos ${ }^{1 *}$, YeeWen Candace Wu ${ }^{1}$, Amy S. Williams ${ }^{2}$, Linda K. Byrne ${ }^{2}$
}

${ }^{1}$ Florey Institute of Neuroscience and Mental Health, University of Melbourne, VIC, Australia; ${ }^{2}$ School of Psychology, Deakin University, Burwood, VIC, Australia.

*Correspondence to:

Dr Andrea Gogos

Florey Institute of Neuroscience and Mental Health

Kenneth Myer Building

University of Melbourne, VIC 3010, Australia

Phone +6139035 6798, Fax +61390353107

E-mail: agogos@unimelb.edu.au 


\begin{abstract}
Oral contraceptives (OCs), often referred to as "the pill", are the most commonly employed form of reversible contraception. OCs are comprised of combined synthetic estrogen and progestin, which work to suppress ovulation and subsequently protect against pregnancy. To date, almost 200 million women have taken various formulations of OC, making it one of the most widely consumed classes of medication in the world. While a substantial body of literature has been dedicated to understanding the physical effects of OCs, much less is known about the long term consequences of OC use on brain anatomy and the associated cognitive effects. Accumulating evidence suggests that sex hormones may significantly affect human cognition. This phenomenon has been commonly studied in older populations, such as in post-menopausal women, while research in healthy, pre-menopausal women remains limited. The current review focused on the effects of OCs on human cognition, with the majority of studies comparing pre-menopausal OC users to naturally cycling women. Human neuroimaging data and animal studies are also described herein. Taken together, the published findings on OC use and human cognition are varied. Of those that do report positive results, OC users appear to have improved verbal memory, associative learning and spatial attention. We recommend future research to employ blinding procedures and randomised designs. Further, more detailed information pertaining to the specific generation and phasic type of OCs, as well as menstrual cycle phase of the OC non-users should be considered to help unmask the potential impact of OC use on human cognition.
\end{abstract}

\title{
Keywords
}

Cognition, Oral contraceptive (OC), Estrogens, Progestins, Sex hormones, Women 


\section{Introduction}

The oral contraceptive pill (OC) is the most widely employed form of reversible contraception. To date, almost 200 million women, at ages ranging from puberty to pre-menopause, have taken various formulations of OC [1], yet the exact long-term consequences of OC use on human cognition remain unknown. Such information is essential for informing women on all the possible effects associated with OC use.

Estrogens and progesterone ( $\mathrm{P} 4)$ are sex steroid hormones predominantly found in women, but are also present in lower concentrations in men. Women produce three major forms of estrogen including estrone (E1), 17 estradiol (E2) and estriol (E3), with E2 being the most bioactive and potent estrogen under normal physiological conditions $[2,3]$. During the menstrual cycle, there are two peaks of E2 secretion, one just before ovulation and a smaller one during the mid-luteal phase. P4 levels remain low during the follicular phase and there is one peak in its secretion during the mid-luteal phase $[2,3]$. Sex steroid hormones are primarily produced by the ovaries in women, but may also be synthesized by the brain [2-4]. In fact, the central nervous system (CNS) is a major target of sex steroid hormone action and shows a high expression of sex hormone receptors [5]. There are a number of overlapping regions of expression between the sex hormone receptors including the forebrain and hippocampus, which support a role of sex hormones on functions other than the reproduction system [6, 7]. Indeed, sex hormones have been implicated in brain development, mood and cognition. Numerous studies suggest that estrogens, especially E2, have neurotrophic effects, improve cerebral blood flow, and promote synaptic plasticity and myelination [8]. Several major neurotransmitter systems are modulated by estrogens, including the dopaminergic and glutamatergic pathways $[9,10]$. Acute applications of E2 also have anti-oxidant [11] and anti-apoptotic properties [12].

There are two types of widely available oral contraceptive pills that are either progestin only or the combined OC, containing both a synthetic estrogen and progestin. Although administration of each of these exogenous sex hormones alone is able to prevent ovulation, combined administration of both greatly increases efficacy [13]. Combined OCs can be comprised of mono-, bi- or tri-phasic formulations, referring to the number of different doses of hormones administered throughout the cycle of pills. Monophasic pills administer a consistent and stable amount of hormones across the cycle, while bi- and tri-phasic formulations administer increasing amounts of hormones, in an attempt to imitate the fluctuations observed during the natural menstrual cycle $[14,15]$. Ethinylestradiol $(\mathrm{EE})$ is a synthetic form of the endogenously-circulating E2 and is by far the 
most commonly used form of estrogen in OCs. In contrast, the progestin component varies with each brand. There are currently three generations of progestins. These progestins and their metabolites show distinct biological properties such as their binding affinity to steroid receptors and their transactivational activity on these receptors. For instance, the second generation progestins are often derived from testosterone and are thus more androgenic compared to the third generation progestins, whereas the new progestins (fourth generation) are anti-androgenic $[14,16]$. Endogenous hormone levels may be dramatically reduced in women using the OC [17], while the levels of synthetic sex hormones used in OCs are generally high [18]. Importantly, EE, which is prescribed in most OCs, cannot be converted to E1 or other weaker estrogens, making EE more potent than the endogenous E2 [19]. Despite this evidence, the existing clinical and preclinical research on the cognitive impact of EE is limited with inconsistent findings.

Emerging clinical data suggest that estrogens can significantly affect cognition, particularly verbal memory [20, 21]. This phenomenon has been most studied in post-menopausal women and in populations vulnerable to cognitive decline such as those with Alzheimer's disease [20, 22, 23]. However, the outcome of these studies seems to depend on the specific cognitive domain [24], type of estrogen [25], whether women are experiencing menopausal symptoms [26] and the time frame of when the estrogen was administered [21, 22, 27]. In naturally cycling women, verbal memory was found to be enhanced during the high E2 and P4 phase of the menstrual cycle [21, 28-30]. Further, Maki and colleagues (2002) found that E2 levels correlated positively with verbal fluency and negatively with mental rotation, suggesting that E2, and not P4, selectively modulates verbal cognition [29]. Here, we reviewed the clinical (Table 1) and preclinical research on the effects of sex steroid hormones, OC use, and menstrual phase on cognition, in an attempt to consolidate the existing findings and to identify new directions for future research which may help better unmask the exact impact of OC use on human cognition.

\section{The effects of OCs on human cognition}

\subsection{The effects of OCs on lower-order cognition}

Prepulse inhibition (PPI) of the startle reflex is a cross-species phenomenon which measures sensorimotor gating, a form of CNS inhibition wherein irrelevant sensory information is filtered out so that attention can be focused on more salient features of the environment [31]. A deficit in PPI is thought to reflect cognitive 
fragmentation and has been associated with mental disorders with cognitive symptoms such as schizophrenia. We have previously tested PPI in healthy, pre-menopausal women who were OC users, naturally cycling women in either the early follicular (low E2 and P4) or mid-luteal (high E2/P4) phase of the menstrual cycle, and healthy male controls. Overall, we found no significant differences between the four groups [32] similar to another study showing no difference in PPI between post-menopausal women who were either users or nonusers of hormone replacement therapy [33]. One study found that women with adverse mood-related sideeffects from OC use had lower levels of PPI, compared to women with no adverse effects of the OC [34], highlighting the role of adverse mood on PPI in OC users. In a separate analysis, we compared PPI in naturally cycling women only, and found greater PPI during the early follicular phase of the cycle, compared to the midluteal phase, under certain stimulus conditions [32]. This is in agreement with previous literature examining the effects of menstrual cycle phase on PPI [35-37]. A previous study from our group also found that acute E2 administration in healthy pre-menopausal women had no effect on baseline PPI [38].

The classically conditioned eye-blink response task, used as a measure of associative learning, was tested by Beck and colleagues (2008) in OC users and non-users. Their study was further separated according to menstrual cycle phase for non-users (early follicular, ovulatory or mid-luteal) and OC users were tested at these same cycle times for comparison, whereby the early follicular phase corresponds to inactive pills and the other two cycle phases correspond to active pills (and thus high synthetic estrogen/progestin levels) [39]. OC users acquired the conditioned eye-blink response quicker than non-users. Moreover, OC users, but not non-users, showed improved acquisition during the ovulatory (active pill) phase compared to the early follicular (inactive pill) phase. The authors concluded that high levels of synthetic sex hormones, as found in the active pills of the OC, may facilitate associative learning. However, it should be noted that these results were confounded by concurrently increased startle reactivity [39]. In a subsequent study, Holloway et al. (2011) used the PPI paradigm in the same participants undergoing the classical conditioning eye-blink task. The OC users and nonusers, were separated by cycle phase (follicular or luteal) and the study also included male controls. It should be noted that it is unclear if the OC users were tested during active and/or inactive pills in the follicular phase, limiting the conclusions that can be made. The main finding by Holloway et al (2011) was similar to that of Beck et al. (2008) in that OC users performed better on the classical conditioning task compared to non-users, and also outperformed men, highlighting a gender difference in this task [40]. Under certain stimulus conditions, Holloway and colleagues (2011) reported lower PPI in males and OC users compared to female nonusers [40]. Given their PPI protocol was vastly different to the one used in our previous study [32], it is difficult 
to make direct comparisons. Unfortunately, Holloway and colleagues (2011) did not report PPI analysis of OC users across cycle phase or OC type. To our knowledge, there is no other human research that examines lowerorder cognition.

\subsection{The effects of OCs on higher-order cognition}

In this section, a variety of tasks, broadly defined as higher-order cognition, have been employed across studies. For example, working memory is the ability to focus attention, hold information in the mind and perform some active task with that information over a very short space of time. It can further be separated depending on whether the stimulus is verbal or visuospatial. This cognitive ability is an area that has attracted considerable interest in OC research but has been measured in a variety of ways. Gogos (2013) employed standard neuropsychological paper and pencil tasks where the immediate and delayed memory domains combined both verbal and non-verbal tasks [32]. Other studies [17, 30, 41] all employed more typical verbal working memory measures. In contrast, Vranic and Hromatko (2008) used a novel visual working memory task where participants had to remember the location of either babies, or male faces [42]. Mental rotation is another domain that has been of interest, due to reported sex differences where males are more superior on some tasks of spatial abilities [43]. These tasks require the mental manipulation of visuospatial objects or designs. Several of the studies reviewed $[14,17,44]$ employed this type of task. Due to the breadth of measures across studies, we have separated the studies here by comparisons between naturally cycling woman and OC users, within group comparisons across the menstrual cycle and between OC types rather than by cognitive domain.

\subsubsection{Comparison between OC users and naturally cycling women}

In the same study where we examined PPI [32], higher-order cognitive function was also measured using the Repeatable Battery for the Assessment of Neuropsychological Status (RBANS). The RBANS gives an overall indication of cognitive performance plus five domain scores including immediate learning/memory, delayed memory, attention, language and visuospatial/constructional ability. We found marked gender differences in overall cognitive function, when comparing OC users, follicular phase women, mid-luteal phase women and men. Specifically, OC users and mid-luteal phase non-users performed similarly and outperformed men [32]. Further, there was a tendency for OC users to outperform early follicular phase non-users, who performed similarly to men. This effect was mostly due to changes in the cognitive domains of immediate and delayed 
memory, and attention [32]. These results suggest that exogenous administration or high levels of natural circulating sex hormones, as occurs with OC use or during the mid-luteal phase of the menstrual cycle, respectively, has a positive effect on higher-order cognition, particularly memory. A study conducted by Vranic and Hromatko (2008) separated the cycle phases of their participants (inactive pills/early follicular or active pills/other cycle phases). While they found no difference in working memory between OC users and non-users, they found greater efficiency in solving a content-specific working memory task during high hormone level phases, regardless of whether the hormone phase was naturally- or OC- induced [42]. McFadden (2000) found that the spatial performance of OC users was intermediate to males and OC non-users in the mid-luteal phase, with males showing the best spatial performance scores [45]. Hence, they suggest that OC use may produce a weak masculinising effect. This notion is congruent with other studies describing differing levels of androgenicity associated with various types of OC [14], although the generation of OC was not reported in the study by McFadden (2000). Moreover, preliminary evidence indicates that long-term OC use in premenopausal women may influence their midlife cognitive outcomes, even years following discontinued use [46]. Egan and Gleason (2012) found that OC ever users performed significantly better than never users in the domains of visuospatial ability as well as speed and flexibility. The authors reported duration-dependent increases in cognitive performance, especially in ever users with more than 15 years of use [46]. However, there was a lack of data on the generation of OC used which prevented the authors from determining if the generation of OC impacted cognition in ever users. One group measured emotional memory and found no difference between OC users and non-users for overall total recall of an emotional story [47, 48]. Interestingly, OC users had enhanced memory for gist whereas non-users recalled more details of the emotional story [47]. Although participants were tested twice, one week apart, this study did not report the cycle phase of their participants at either testing time. A recent study by Graham and Milad (2013) found that women using combined monophasic OCs exhibit impaired extinction recall compared to naturally cycling women who were categorised as having high estrogen serum levels [49]. Collectively, the abovementioned studies show no clear pattern of cognitive differences between OC users and non-users. Instead it appears that differences may be the result of the variation in hormone levels (regardless of whether this is naturally occurring or exogenously administered) and these effects are task- and context- dependent. 
Hormonal variations during the menstrual cycle have been shown to influence cognitive function and may act as a confounding factor in the study of OC users and non-users. The following section describes a series of studies where women were tested on more than one occasion during the cycle to discern, in more detail, the cognitive performance among OC users and non-users.

A study conducted by Mordecai et al. (2008) demonstrated that OC users have enhanced verbal memory (as assessed using the California Verbal Learning Test) during the active pill phase compared to the inactive pill phase, while naturally cycling women showed no change across the menstrual cycle [17]. In contrast, Islam and colleagues (2008) found no significant difference between OC users and non-users on verbal memory (assessed using a Paragraph Recall task) across the early luteal/active pill phase and the early follicular/inactive pill phase. The main difference between these two studies is the verbal memory task; however, the inconsistent findings may also be due to different testing days (early-luteal vs mid-luteal) or a smaller sample size in the Islam et al. (2008) study. Both Mordecai et al. (2008) and Islam et al. (2008) also examined a battery of other cognitive tasks including object memory, working memory, verbal fluency, verbal learning, visuospatial mental rotation and attention. However, no significant differences between OC users and non-users were found in any of these other cognitive measures $[17,41]$. When comparing naturally cycling women across the cycle, there was a significant effect of a greater rate of learning on a verbal learning task during the early follicular phase compared to the luteal phase [41]. A lack of effect of OC use on verbal memory, visual memory and visual motor processing speed, was also documented by Mihalik and colleagues (2009), who examined their participants (OC users and non-users) during the mid-follicular phase (3-5 days after menstruation cessation) and the late luteal phase (4-6 days before menstruation) [50]. However, this study [50] does not clearly state whether the two testing phases correspond to inactive vs active pills, and if we simply use the days they have listed, both phases were during active pills in OC users and low-medium levels of sex hormones in non-users. Thus the lack of a significant effect may be due to testing occurring during phases that were not markedly different from each other in terms of circulating hormones.

Rosenberg and Park (2002) tested OC users and non-users on verbal working memory and spatial ability using a repeated-measures design where they tested participants across 4 separate test days (days 1, 7, 14 and 21). Although no differences in performance were found on either cognitive tasks between OC users and non-users, a significant effect of cycle phase was uncovered [30]. Specifically, non-users had improved verbal working 
memory during days 7 and 14 (mid- to late-follicular phase, a time of increasing estrogens) compared to days 1 and 21 (early follicular phase and mid-luteal phase respectively). These findings suggest that increasing natural E2 levels, in the absence of P4, may positively regulate verbal working memory. In other words, the addition of P4 may have opposed the beneficial effects of E2. Rather than comparing OC users with non-users, one study examined OC users during the active and inactive pill phases [51]. An important advantage of this study was that all OC users were on the same type of OC, the combined, monophasic OC, Yasminelle, which contains EE and the new generation progestin, drospirenone. Using this more homogenous sample, in terms of OC type, the authors found that women on active OC pills had enhanced spatial attention as measured by a line bisection task [51]. Overall, limited evidence suggests that cycle phase may influence verbal learning/memory and spatial attention, but not other cognitive domains.

\subsubsection{Comparison across types of OCs}

As alluded to above, the type of OC may significantly impact the outcome of cognitive performance between OC users and non-users. In particular, second, third and new generation OCs differ in their progestin compound and thus their androgenicity or androgen receptor binding potential $[14,44]$. This may act as a potential factor driving the inconsistencies among the existing literature. Indeed, a study by Wharton et al. (2008) assessed visuospatial mental rotation in OC users and non-users that were grouped according to three types of OCs (second generation/ monophasic/ most androgenic, third generation/ triphasic/ less androgenic and new generation/ monophasic/ anti-androgenic) and three phases of the menstrual cycle (menstrual, follicular and luteal phase groups). The OC non-users (all phases combined) displayed better performance on the mental rotation task compared to the new generation OC users, while second generation OC users tended to outperform non-users [14]. Finally, this study found no differences across groups, cycle phase or OC type in the recognition memory task [14]. In contrast, Griksiene and Ruksenas (2011) found that third generation (androgenic) OC users performed worse on the mental rotation task, where they required longer reaction times, compared to OC non-users. Moreover, third generation OC users performed poorly on a verbal fluency task, compared to new generation (anti-androgenic) OC users and also to non-users [44]. While third generation OCs are generally triphasic and new generation OCs are generally monophasic, this study eliminated this potential confound by only including participants using monophasic OCs. Thus, it is likely that the observed differences between third and new generation OC users are due to differences in the type of progestin used, where the androgenic nature 
of third generation OCs results in poorer performance, particularly on verbal fluency, compared to antiandrogenic progestins. It should be noted that the study by Griksiene and Ruksenas (2011) had less participants than the Wharton et al. (2008) study, and the mental rotation tasks used were different among the two studies. Overall, the available evidence suggests that mental rotation is influenced by generation-specific OC use; however the direction of this effect is unclear. Further, the androgenic nature of the OC may influence verbal fluency, but not recognition memory.

\subsection{The effects of OCs on brain structure and activation}

A small number of studies have shown that OCs may alter brain structure and activation patterns in regions that are associated with higher-order cognition. Using magnetic resonance imaging (MRI), OC users were found to have significantly larger prefrontal cortices, pre- and post-central gyri, parahippocampal and fusiform gyri, and temporal regions, compared to OC non-users [52]. A significant difference in white matter microstructure has also been reported. Using diffusion tensor imaging, OC users were found to show an increased mean diffusivity in the fornix compared to naturally cycling women [53]. Further, the mean diffusivity values in the fornix were negatively correlated with E2 blood concentrations [53]. During verb generation using functional MRI, OC users showed greater activation in the right hemisphere compared to OC non-users in the menstrual phase in the superior temporal and in the luteal phase in the inferior frontal cortex [54]. Although the quality and quantity of the performance did not differ between each group, these results provide evidence for the importance of hormonal influence in gender-specific cortical activation patterns. Furthermore, during face processing, OC users showed stronger neural responses to faces in the right fusiform face area, compared to naturally cycling women [55]. Recently, cognitive performance and brain activation patterns of OC users were evaluated in two distinct numerical tasks (number comparison and number bisection), and compared to OC non-users and men [56]. During both tasks, OC users showed similar behavioural performance as naturally cycling women, but displayed male-like brain activation patterns [56]. Another study compared the resting state networks associated with cognition in women using combined OC and naturally cycling women [57]. The connectivity of the anterior cingulate cortex and left middle frontal gyrus, two important regions for higher-order cognitive processing, were found to be lower in OC users and women in the luteal phase relative to either the inactive OC users or women in the follicular phase [57]. Together, these studies further support the likelihood that OC use can affect cognitive abilities. 


\section{$3 \quad$ Animal studies on sex hormones and cognition}

Rodent and non-human primate studies have provided a more direct link between sex hormones, especially estrogens, and cognition. To date, E2 has been the primary estrogen used in preclinical research. For example, E2 treatment in hormone deprived young and middle-aged rodents, via surgical ovariectomy (OVX), enhanced spatial memory and visual object recognition performance [58-61]. Similarly, E2 administration in young OVX monkeys enhanced visuospatial attention [62]. Given that both verbal and spatial memory relies on the integrity of the hippocampus [63-65], testing spatial memory in animals may be a clinically relevant model for evaluating the link between sex hormones and human-specific cognitive tasks such as verbal memory. Indeed, recent work in humans suggests that the same place cells in the hippocampus that represent location during spatial navigation also code elements of verbal recall [66].

Due to the presence of an ethinyl group, EE has a higher affinity to estrogen receptors and thus greater estrogenic activity than the endogenous E2 in the brain and body [67]. For instance, while both oral E2 and EE treatments inhibit the onset of experimental autoimmune encephalomyelitis in mice, only EE was able to suppress the clinical severity when given after the onset of clinical symptoms [67]. Despite the higher affinity to estrogen receptors, the animal literature on $\mathrm{EE}$ and cognition is very limited compared to that of E2. Only one study has assessed the effects of EE on cognitive function in young OVX rhesus monkeys [68]. In this study, monkeys were tested on four cognitive tasks assessing visual recognition memory (Matching-to-Sample, object, face and spatial conditions of the Delayed Recognition Span Test (DRST)), while receiving placebo or EE in alternating 28-days blocks [68]. The authors observed that periods of EE treatment impaired face-DRST performance whereas performances on other tasks were unaffected. Further studies with additional categories of faces (rhesus monkeys, chimpanzees and humans) revealed that EE treatment was associated with poor performance for faces of conspecifics only, indicating that EE disrupted the processing of socially relevant stimuli [68]. Other studies on aged OVX rhesus monkeys found a significant improvement in the spatial-DRST following EE treatment [69] but not in a cognitive flexibility task (monkey version of the Wisconsin Card Sort Test) [70]. Another study showed that aged OVX rhesus monkeys performed marginally worse than their intact counterparts on the delayed nonmatching-to-sample task, but outperformed them on the spatial-DRST [71]. A range of factors such as the duration of hormone deprivation, the type of cognitive task and the subject's age, can all influence the effect that EE has on cognition. It is thus essential to consider the aforementioned factors 
before generalising the effects of EE in animal studies to human cognition in young, pre-menopausal women. Other work in aged rats has identified P4 as the spatial memory deficit inducing agent in intact animals $[72,73]$. In fact, previous studies suggest an antagonistic relationship between P4 and E2 in middle-aged OVX rats, where P4 prevented the E2-induced enhancement of spatial memory [74]. Further, P4 inhibits E2-induced increases in mossy fiber sprouting and spine density in the rodent hippocampus [75] and reduces estrogen receptor hybridization signals in the primate brain [76]. Taken together, the available animal data support an effect of EE on cognition, especially in the face processing and spatial domains. Moreover, they highlight the need to consider the generation of progestins in the study of OCs on cognitive function.

\section{$4 \quad$ Summary and future directions}

The available clinical and preclinical data on the cognitive effects of OC use is limited and varied. There is marked methodological variability among the studies and limited sample sizes (Table 1). The majority of studies have compared OC users with non-users; some have also compared across the cycle phase and OC generation type. Improved performance in the cognitive domain of verbal memory was found when comparing OC users to non-users [32], active vs. inactive pills in OC users [17], and with increasing E2 levels in naturally cycling women [30]. However, not all studies found changes in verbal memory [41, 50]. OC users outperformed non-users on associative learning using the conditioned eye-blink response [39, 40], while active OC pills improved spatial attention compared to inactive pills [51]. Two studies reported significant effects of OC generation (and thus OC androgenicity) on verbal fluency and mental rotation $[14,44]$. In contrast, some found no overall group differences in spatial ability [17, 30, 32], verbal fluency [17, 41] and attention [17, 41, 47]. Taken together, the existing findings suggest that $\mathrm{OC}$ use has specific rather than global effects on cognitive function, which may be better revealed when the cycle phase and OC type are accounted for.

Most studies employed a cross-sectional design but none implemented a randomised control trial, perhaps owing to the nature of the intervention being investigated. Whilst some studies attempted to pseudo-randomly assign participants to certain groups (i.e. cycle phase), the conditions were self-selected by participants. Although difficult to discern, differences may exist between those individuals choosing to use hormonal contraceptives and those who do not, which may ultimately influence study outcomes. Here, we reviewed studies which have recruited self-selected OC users instead of using random allocation, thus these OC users are likely to be women 
who respond well to the OC [17, 33], have a 'risk avoidance' personality style [40], or are more sexually active or of a certain sexual orientation. Rahman and colleagues found sexual orientation-related differences in verbal fluency and spatial memory [77, 78]. Further, due to this self-selection factor, there were also no blinding measures reported for either participants or examiners, raising further questions regarding the validity of outcomes across all studies. Of those participant features that were directly observable, it appears that participant demographics were rather homogenous across studies, with recruitment occurring predominantly from university settings. The average age of participants across all studies included in this review was 21 years of age (Table 1). The fact that participant groups were generally aged in their late teens to early twenties may yield important implications regarding the generalizability of results. OCs may influence cognition differently across the life span and women of all ages use OCs. Researching the effects of OCs on cognitive ability in healthy, pre-menopausal women of all ages is therefore needed in order to adequately capture any differences which may exist across the normal ageing process.

There are considerable discrepancies among the existing studies in terms of the cycle phases and cognitive tasks tested (Table 1) as well as the information provided on the OC type (generation, phase and doses). Only a few studies conducted hormone assays to confirm the menstrual cycle phase of OC non-users. The aforementioned factors may collectively be a major source of inconsistency among study outcomes and should be seriously considered in future research. We recommend conducting randomised control trials, or at least repeated testing across appropriate cycle phases. Future research should also employ cognitive tests that have been widely used, are well validated and can be easily replicated. There appears to be an emerging distinction between the cognitive effects of second-, third- and new generation OCs. Therefore, an important future direction for all studies is to record and group OC users according to the specific generation and phasic type of OC. Finally, understanding the neurobiology underlying the changes in cognition with OC use is a critical next step, where neuroimaging techniques and preclinical animal studies may be particularly useful.

\section{Conclusions}

The present review has summarised the existing literature on the effects of OC use on cognitive function in healthy, pre-menopausal women. Human neuroimaging data of OC users and animal studies using EE were also described. The existing literature on this matter is limited with varied methodologies and thus varied results. 
Nevertheless, significant effects on cognition with OC use have been observed. This field of research warrants further investigation given that almost every woman in developed nations will face the decision of whether to take synthetic hormones as a form of contraception or not. We believe that OC use may have a significant impact on human cognition but that such effects have not been robustly reported due to methodological factors in the available studies. It is clear that much more research is required to fully understand the impact of OC use on cognitive function.

\section{Acknowledgements}

The authors gratefully acknowledge the financial support of the Australian Research Council (A. Gogos, DECRA). The Florey Institute of Neuroscience and Mental Health acknowledge the support from the Victorian Government's Operational Infrastructure Support Grant.

\section{References}

1. Chadwick, K.D., et al., Fifty years of "the pill": risk reduction and discovery of benefits beyond contraception, reflections, and forecast. Toxicol Sci, 2012. 125(1): p. 2-9.

2. Ross, G.T. and R.L. Vande Wiele, The ovaries, in Textbook of Endocrinology, R.H. Williams, Editor 1974, W. B. Saunders: Philadelphia. p. 368-393.

3. Ganong, W.F., Review of Medical Physiology. 9th ed1979, California, USA: Lange Medical Publications. 340-350.

4. Simpson, E., et al., Local estrogen biosynthesis in males and females. Endocr Relat Cancer, 1999. 6(2): p. 131-7.

5. Ozawa, H., Steroid Hormones, their receptors and neuroendocrine system. J Nippon Med Sch, 2005. 72(6): p. 316-25.

6. Srivastava, D.P., K.M. Woolfrey, and P. Penzes, Insights into rapid modulation of neuroplasticity by brain estrogens. Pharmacol Rev, 2013. 65(4): p. 1318-50.

7. Ishii, H., et al., Local production of sex hormones and their modulation of hippocampal synaptic plasticity. Neuroscientist, 2007. 13(4): p. 323-34.

8. Wu, Y.C., et al., Sex differences and the role of estrogen in animal models of schizophrenia: interaction with BDNF. Neuroscience, 2013. 239: p. 67-83.

9. Sanchez, M.G., et al., Steroids-dopamine interactions in the pathophysiology and treatment of CNS disorders. CNS Neurosci Ther, 2010. 16(3): p. e43-71.

10. Finocchi, C. and M. Ferrari, Female reproductive steroids and neuronal excitability. Neurol Sci, 2011. 32 Suppl 1: p. S31-5.

11. Goodman, Y., et al., Estrogens attenuate and corticosterone exacerbates excitotoxicity, oxidative injury, and amyloid beta-peptide toxicity in hippocampal neurons. J Neurochem, 1996. 66(5): p. 183644.

12. Garcia-Segura, L.M., et al., Estradiol upregulates Bcl-2 expression in adult brain neurons. Neuroreport, 1998. 9(4): p. 593-7. 
13. Rivera, R., I. Yacobson, and D. Grimes, The mechanism of action of hormonal contraceptives and intrauterine contraceptive devices. Am J Obstet Gynecol, 1999. 181(5 Pt 1): p. 1263-9.

14. Wharton, W., et al., Oral contraceptives and androgenicity: influences on visuospatial task performance in younger individuals. Exp Clin Psychopharmacol, 2008. 16(2): p. 156-64.

15. Van Vliet, H.A., et al., Biphasic versus monophasic oral contraceptives for contraception. Cochrane Database Syst Rev, 2006. 3: p. CD002032.

16. Lawrie, T.A., et al., Types of progestogens in combined oral contraception: effectiveness and sideeffects. Cochrane Database Syst Rev, 2011(5): p. CD004861.

17. Mordecai, K.L., L.H. Rubin, and P.M. Maki, Effects of menstrual cycle phase and oral contraceptive use on verbal memory. Horm Behav, 2008. 54(2): p. 286-93.

18. DiLiberti, C.E., et al., Steady-state pharmacokinetics of an extended-regimen oral contraceptive with continuous estrogen. Contraception, 2011. 83(1): p. 55-61.

19. Prokai-Tatrai, K. and L. Prokai, Impact of metabolism on the safety of estrogen therapy. Ann N Y Acad Sci, 2005. 1052: p. 243-57.

20. Zec, R.F. and M.A. Trivedi, The effects of estrogen replacement therapy on neuropsychological functioning in postmenopausal women with and without dementia: a critical and theoretical review. Neuropsychol Rev, 2002. 12(2): p. 65-109.

21. Sherwin, B.B., Estrogen and cognitive functioning in women: Lessons we have learned. Behav Neurosci, 2012. 126(1): p. 123-7.

22. Craig, M.C., et al., The interactive effect of acute ovarian suppression and the cholinergic system on visuospatial working memory in young women. Psychoneuroendocrinology, 2010. 35(7): p. 987-1000.

23. Janicki, S.C. and N. Schupf, Hormonal influences on cognition and risk for Alzheimer's disease. Curr Neurol Neurosci Rep, 2010. 10(5): p. 359-66.

24. Bayer, U. and M. Hausmann, Estrogen therapy affects right hemisphere functioning in postmenopausal women. Horm Behav, 2009. 55(1): p. 228-34.

25. Maki, P.M. and E. Sundermann, Hormone therapy and cognitive function. Hum Reprod Update, 2009. 15(6): p. 667-81.

26. LeBlanc, E.S., et al., Hormone replacement therapy and cognition: systematic review and metaanalysis. Jama, 2001. 285(11): p. 1489-99.

27. Maki, P.M., Hormone therapy and cognitive function: is there a critical period for benefit? Neuroscience, 2006. 138(3): p. 1027-30.

28. Hampson, E., Variations in sex-related cognitive abilities across the menstrual cycle. Brain Cogn, 1990. 14(1): p. 26-43.

29. Maki, P.M., J.B. Rich, and R.S. Rosenbaum, Implicit memory varies across the menstrual cycle: estrogen effects in young women. Neuropsychologia, 2002. 40(5): p. 518-29.

30. Rosenberg, L. and S. Park, Verbal and spatial functions across the menstrual cycle in healthy young women. Psychoneuroendocrinology, 2002. 27(7): p. 835-41.

31. Braff, D.L., M.A. Geyer, and N.R. Swerdlow, Human studies of prepulse inhibition of startle: normal subjects, patient groups, and pharmacological studies. Psychopharmacology (Berl), 2001. 156(2-3): p. 234-58.

32. Gogos, A., Natural and synthetic sex hormones: effects on higher-order cognitive function and prepulse inhibition. Biol Psychol, 2013. 93(1): p. 17-23.

33. Bannbers, E., et al., Lower levels of prepulse inhibition in luteal phase cycling women in comparison with postmenopausal women. Psychoneuroendocrinology, 2010. 35(3): p. 422-9.

34. Borgstrom, A., et al., Patients with adverse mood effects from combined oral contraceptives have lower levels of prepulse inhibition than healthy controls. Psychoneuroendocrinology, 2008. 33(4): p. 487-96.

35. Swerdlow, N.R., P.L. Hartman, and P.P. Auerbach, Changes in sensorimotor inhibition across the menstrual cycle: implications for neuropsychiatric disorders. Biol Psychiatry, 1997. 41(4): p. 452-60.

36. Jovanovic, T., et al., Menstrual cycle phase effects on prepulse inhibition of acoustic startle. Psychophysiology, 2004. 41(3): p. 401-6.

37. Kumari, V., et al., Evidence for a role of progesterone in menstrual cycle-related variability in prepulse inhibition in healthy young women. Neuropsychopharmacology, 2010. 35(4): p. 929-37.

38. Gogos, A., et al., Estrogen prevents 5-HT $T_{1 A}$ receptor-induced disruptions of prepulse inhibition in healthy women. Neuropsychopharmacology, 2006. 31(4): p. 885-889.

39. Beck, K.D., et al., Facilitated acquisition of the classically conditioned eyeblink response in women taking oral contraceptives. Behav Pharmacol, 2008. 19(8): p. 821-8.

40. Holloway, J.L., K.D. Beck, and R.J. Servatius, Facilitated acquisition of the classically conditioned eyeblink response in females is augmented in those taking oral contraceptives. Behav Brain Res, 2011. 216(1): p. 301-7. 
41. Islam, F., et al., Short-term changes in endogenous estrogen levels and consumption of soy isoflavones affect working and verbal memory in young adult females. Nutr Neurosci, 2008. 11(6): p. 251-62.

42. Vranic, A. and I. Hromatko, Content-specific activational effects of estrogen on working memory performance. J Gen Psychol, 2008. 135(3): p. 323-36.

43. Voyer, D., S. Voyer, and M.P. Bryden, Magnitude of sex differences in spatial abilities: a metaanalysis and consideration of critical variables. Psychological Bulletin, 1995. 117(2): p. 250-70.

44. Griksiene, R. and O. Ruksenas, Effects of hormonal contraceptives on mental rotation and verbal fluency. Psychoneuroendocrinology, 2011. 36(8): p. 1239-48.

45. McFadden, D., Masculinizing effects on otoacoustic emissions and auditory evoked potentials in women using oral contraceptives. Hear Res, 2000. 142(1-2): p. 23-33.

46. Egan, K.R. and C.E. Gleason, Longer duration of hormonal contraceptive use predicts better cognitive outcomes later in life. J Womens Health (Larchmt), 2012. 21(12): p. 1259-66.

47. Nielsen, S.E., et al., Hormonal contraception usage is associated with altered memory for an emotional story. Neurobiol Learn Mem, 2011. 96(2): p. 378-84.

48. Nielsen, S.E., et al., Hormonal contraception use alters stress responses and emotional memory. Biol Psychol, 2013. 92(2): p. 257-66.

49. Graham, B.M. and M.R. Milad, Blockade of estrogen by hormonal contraceptives impairs fear extinction in female rats and women. Biol Psychiatry, 2013. 73(4): p. 371-8.

50. Mihalik, J.P., et al., The effects of menstrual cycle phase on clinical measures of concussion in healthy college-aged females. J Sci Med Sport, 2009. 12(3): p. 383-7.

51. Cicinelli, E., et al., Oral contraceptive therapy modulates hemispheric asymmetry in spatial attention. Contraception, 2011. 84(6): p. 634-6.

52. $\quad$ Pletzer, B., et al., Menstrual cycle and hormonal contraceptive use modulate human brain structure. Brain Res, 2010. 1348: p. 55-62.

53. De Bondt, T., et al., Does the use of hormonal contraceptives cause microstructural changes in cerebral white matter? Preliminary results of a DTI and tractography study. Eur Radiol, 2013. 23(1): p. 57-64.

54. Rumberg, B., et al., Cycle and gender-specific cerebral activation during a verb generation task using fMRI: comparison of women in different cycle phases, under oral contraception, and men. Neurosci Res, 2010. 66(4): p. 366-71.

55. Mareckova, K., et al., Hormonal contraceptives, menstrual cycle and brain response to faces. Soc Cogn Affect Neurosci, 2014. 9(2): p. 191-200.

56. Pletzer, B., et al., Hormonal contraceptives masculinize brain activation patterns in the absence of behavioral changes in two numerical tasks. Brain Res, 2014. 1543: p. 128-42.

57. Petersen, N., et al., Oral contraceptive pill use and menstrual cycle phase are associated with altered resting state functional connectivity. Neuroimage, 2014. 90: p. 24-32.

58. Bimonte, H.A. and V.H. Denenberg, Estradiol facilitates performance as working memory load increases. Psychoneuroendocrinology, 1999. 24(2): p. 161-73.

59. Lewis, M.C., et al., Estradiol-induced enhancement of object memory consolidation involves NMDA receptors and protein kinase $A$ in the dorsal hippocampus of female C57BL/6 mice. Behav Neurosci, 2008. 122(3): p. 716-21.

60. Luine, V.N., L.F. Jacome, and N.J. Maclusky, Rapid enhancement of visual and place memory by estrogens in rats. Endocrinology, 2003. 144(7): p. 2836-44.

61. Markowska, A.L. and A.V. Savonenko, Effectiveness of estrogen replacement in restoration of cognitive function after long-term estrogen withdrawal in aging rats. J Neurosci, 2002. 22(24): p. 10985-95.

62. Voytko, M.L., Estrogen and the cholinergic system modulate visuospatial attention in monkeys (Macaca fascicularis). Behav Neurosci, 2002. 116(2): p. 187-97.

63. Morris, R.G., et al., Place navigation impaired in rats with hippocampal lesions. Nature, 1982. 297(5868): p. 681-3.

64. Nyberg, L., et al., General and specific brain regions involved in encoding and retrieval of events: what, where, and when. Proc Natl Acad Sci U S A, 1996. 93(20): p. 11280-5.

65. Squire, L.R., Memory and the hippocampus: a synthesis from findings with rats, monkeys, and humans. Psychol Rev, 1992. 99(2): p. 195-231.

66. Miller, J.F., et al., Neural activity in human hippocampal formation reveals the spatial context of retrieved memories. Science, 2013. 342(6162): p. 1111-4.

67. Subramanian, S., et al., Oral feeding with ethinyl estradiol suppresses and treats experimental autoimmune encephalomyelitis in SJL mice and inhibits the recruitment of inflammatory cells into the central nervous system. J Immunol, 2003. 170(3): p. 1548-55. 
68. Lacreuse, A. and J.G. Herndon, Estradiol selectively affects processing of conspecifics' faces in female rhesus monkeys. Psychoneuroendocrinology, 2003. 28(7): p. 885-905.

69. Lacreuse, A., M.E. Wilson, and J.G. Herndon, Estradiol, but not raloxifene, improves aspects of spatial working memory in aged ovariectomized rhesus monkeys. Neurobiol Aging, 2002. 23(4): p. 589-600.

70. Lacreuse, A., et al., Executive function is less sensitive to estradiol than spatial memory: performance on an analog of the card sorting test in ovariectomized aged rhesus monkeys. Behav Processes, 2004. 67(2): p. 313-9.

71. Lacreuse, A., J.G. Herndon, and M.B. Moss, Cognitive function in aged ovariectomized female rhesus monkeys. Behav Neurosci, 2000. 114(3): p. 506-13.

72. Bimonte-Nelson, H.A., et al., Ovarian hormones and cognition in the aged female rat: II. progesterone supplementation reverses the cognitive enhancing effects of ovariectomy. Behav Neurosci, 2004.

118(4): p. 707-14.

73. Bimonte-Nelson, H.A., et al., Ovarian hormones and cognition in the aged female rat: I. Long-term, but not short-term, ovariectomy enhances spatial performance. Behav Neurosci, 2003. 117(6): p. 1395406.

74. Bimonte-Nelson, H.A., et al., Progesterone reverses the spatial memory enhancements initiated by tonic and cyclic oestrogen therapy in middle-aged ovariectomized female rats. Eur J Neurosci, 2006. 24(1): p. 229-42.

75. Teter, B., et al., Role of apolipoprotein E and estrogen in mossy fiber sprouting in hippocampal slice cultures. Neuroscience, 1999. 91(3): p. 1009-16.

76. Gundlah, C., et al., Distribution of estrogen receptor beta (ERbeta) mRNA in hypothalamus, midbrain and temporal lobe of spayed macaque: continued expression with hormone replacement. Brain Res Mol Brain Res, 2000. 76(2): p. 191-204.

77. Rahman, Q., S. Abrahams, and G.D. Wilson, Sexual-orientation-related differences in verbal fluency. Neuropsychology, 2003. 17(2): p. 240-6.

78. Rahman, Q., G.D. Wilson, and S. Abrahams, Sexual orientation related differences in spatial memory. J Int Neuropsychol Soc, 2003. 9(3): p. 376-83.

Table 1 - Human studies on the effects of OC use on cognitive function

\begin{tabular}{|c|c|c|c|c|c|c|c|}
\hline $\begin{array}{l}\text { Author } \\
\text { (Year) }\end{array}$ & $\begin{array}{l}\text { Participant } \\
\text { type } \\
\text { (Mean age } \\
\pm \text { SD) }\end{array}$ & OC groups & $\begin{array}{l}\text { Control } \\
\text { groups / } \\
\text { Phase of } \\
\text { menstrual } \\
\text { cycle }\end{array}$ & Study design & $\begin{array}{l}\text { Hormone } \\
\text { assessme } \\
\text { nt }\end{array}$ & $\begin{array}{l}\text { Cognitive } \\
\text { tasks/domai } \\
\text { n measured }\end{array}$ & Outcome \\
\hline $\begin{array}{c}\text { Beck et al. } \\
\text { (2008) }\end{array}$ & $\begin{array}{l}\text { Communi } \\
\text { ty } \\
\text { individual } \\
\mathrm{s} \\
\text { ( } 27 \mathrm{yrs} \text { ) }\end{array}$ & $\begin{array}{l}\text { OC users } \\
\text { Early follicular } \\
(n=12) \\
\text { Ovulatory }(n=17) \\
\text { Mid-luteal }(n=16) \\
\text { Total } n=45\end{array}$ & $\begin{array}{l}\text { Early } \\
\text { follicular, } \\
\text { days 3-7 } \\
\text { ( } n=19) \\
\text { Ovulatory, } \\
\text { days 11-14 } \\
\text { ( } n=15) \\
\text { Mid-luteal, } \\
\text { days 17-25 } \\
\text { ( } n=12 \text { ) } \\
\text { Total } n=46\end{array}$ & $\begin{array}{l}\text { All subjects } \\
\text { tested once. }\end{array}$ & $\begin{array}{l}\text { Urine } \\
\text { hormon } \\
\text { e assays. }\end{array}$ & $\begin{array}{l}\text { - Classically } \\
\text { conditione } \\
\text { d motor } \\
\text { (eye-blink) } \\
\text { response } \\
\text { (i.e. } \\
\text { associative } \\
\text { learning) }\end{array}$ & $\begin{array}{l}\text { 1) OC users acquired the } \\
\text { conditioned eye-blink response } \\
\text { quicker than non-users (i.e. } \\
\text { improved learning in OC users). } \\
\text { 2) OC users showed improved } \\
\text { acquisition during the ovulatory } \\
\text { phase compared to the early } \\
\text { follicular phase. No differences } \\
\text { across cycle phase in non-users. }\end{array}$ \\
\hline $\begin{array}{l}\text { Cicinelli et } \\
\text { al. (2011) }\end{array}$ & $\begin{array}{l}\text { Communi } \\
\text { ty } \\
\text { individual } \\
\mathrm{s} \\
(24 \pm 2.0 \\
\text { yrs) }\end{array}$ & $\begin{array}{l}\text { OC users } \\
\text { (all combined, } \\
\text { monophasic, } \\
\text { 'Yasminelle') } \\
\text { Total } \mathbf{n = 3 6}\end{array}$ & None & $\begin{array}{l}\text { All subjects } \\
\text { tested twice, } \\
\text { on: } \\
\text { 1) day } 10 \text { of } \\
\text { active pills, } \\
\text { 2) day } 7 \text { of }\end{array}$ & $\begin{array}{l}\text { Self- } \\
\text { report. }\end{array}$ & $\begin{array}{l}\text { - Spatial } \\
\text { attention }\end{array}$ & $\begin{array}{l}\text { 1) Active OC pills improved } \\
\text { spatial attention as measured by } \\
\text { a line-bisection task. }\end{array}$ \\
\hline
\end{tabular}




\begin{tabular}{|c|c|c|c|c|c|c|c|}
\hline & & & & $\begin{array}{l}\text { inactive pill } \\
\text { period. }\end{array}$ & & & \\
\hline $\begin{array}{l}\text { Gogos } \\
(2013)\end{array}$ & $\begin{array}{l}\text { Communi } \\
\text { ty } \\
\text { individual } \\
\text { s } \\
(27 \pm 4.9 \\
\text { yrs) }\end{array}$ & $\begin{array}{l}\text { OC users } \\
\text { (all combined } \\
\text { OCs, } \\
\geq \text { day } 9 \text { of active } \\
\text { pills) } \\
\text { Total } n=16\end{array}$ & $\begin{array}{l}\begin{array}{l}\text { Early } \\
\text { follicular, } \\
\text { days 2-8 } \\
(n=15)\end{array} \\
\text { Mid-luteal, } \\
\text { days 19-25 } \\
(n=14) \\
\text { Male } \\
\text { controls } \\
\text { ( } n=15) \\
\text { Total } n=44\end{array}$ & $\begin{array}{l}\text { All subjects } \\
\text { tested once. }\end{array}$ & $\begin{array}{l}\text { Menstru } \\
\text { al cycle } \\
\text { question } \\
\text {-naire. }\end{array}$ & $\begin{array}{l}\text { - RBANS } \\
\text { (immediate } \\
\text { and } \\
\text { delayed } \\
\text { memory, } \\
\text { attention, } \\
\text { language } \\
\text { visuospatia } \\
\text { I ability) } \\
\text {-Prepulse } \\
\text { inhibition } \\
\text { (PPI) }\end{array}$ & $\begin{array}{l}\text { 1) OC users performed similar to } \\
\text { mid-luteal phase women and } \\
\text { better than men on attention } \\
\text { and immediate and delayed } \\
\text { memory, and better than early } \\
\text { follicular phase women on } \\
\text { delayed memory. } \\
\text { 2) Mid-luteal phase women } \\
\text { performed better than men on } \\
\text { delayed memory. } \\
\text { 3) Overall, no differences in PPI } \\
\text { between the groups; early } \\
\text { follicular phase women had } \\
\text { greater PPI than mid-luteal phase } \\
\text { women. }\end{array}$ \\
\hline $\begin{array}{c}\text { Graham \& } \\
\text { Milad } \\
\text { (2013) }\end{array}$ & $\begin{array}{l}\text { Communi } \\
\text { ty } \\
\text { individual } \\
\mathrm{s} \\
(24 \pm 2.8 \\
\text { yrs) }\end{array}$ & $\begin{array}{l}\text { OC users } \\
\text { (all combined, } \\
\text { monophasic) }\end{array}$ & $\begin{array}{l}\text { High } \\
\text { estrogen } \\
\text { serum } \\
\text { levels } \\
\text { ( } n=16) \\
\text { Low } \\
\text { estrogen } \\
\text { serum } \\
\text { levels } \\
\text { ( } n=16) \\
\text { Total } n=32\end{array}$ & $\begin{array}{l}\text { All subjects } \\
\text { tested once. } \\
\text { Phase at time } \\
\text { of testing for } \\
\text { OC users or } \\
\text { naturally } \\
\text { cycling } \\
\text { women was } \\
\text { not recorded. }\end{array}$ & $\begin{array}{l}\text { Blood } \\
\text { serum } \\
\text { hormon } \\
\text { e assays. }\end{array}$ & $\begin{array}{l}\text { - Fear } \\
\text { extinction }\end{array}$ & $\begin{array}{l}\text { 1) OC users exhibited impaired } \\
\text { fear extinction recall compared } \\
\text { to non-users who were } \\
\text { categorised as having high } \\
\text { estrogen serum levels. Non-users } \\
\text { with low estrogen serum levels } \\
\text { performed similar to OC users. } \\
\text { 2) No group differences in } \\
\text { conditioning or acquisition of } \\
\text { extinction. }\end{array}$ \\
\hline $\begin{array}{c}\text { Griksie } \\
\text { ne \& } \\
\text { Ruksen } \\
\text { as } \\
(2011)\end{array}$ & $\begin{array}{l}\text { University } \\
\text { students } \\
\text { ( } 21 \pm 1.8 \\
\text { yrs) }\end{array}$ & $\begin{array}{l}\text { OC users } \\
\text { (all combined, } \\
\text { monophasic): } \\
\text { Third generation } \\
(n=11) \\
\text { New generation } \\
(n=11) \\
\text { Total } \mathbf{n = 2 2}\end{array}$ & $\begin{array}{l}\text { Women } \\
\text { with a } \\
\text { regular, } \\
\text { natural } \\
\text { cycle } \\
\text { Total } \mathbf{n = 2 0}\end{array}$ & $\begin{array}{l}\text { All subjects } \\
\text { tested three } \\
\text { times, during: } \\
\text { 1) early } \\
\text { follicular } \\
\text { phase or } \\
\text { inactive pills } \\
\text { (days 2-5), } \\
\text { 2) ovulatory } \\
\text { phase or } \\
\text { active pills, } \\
\text { 3) luteal } \\
\text { phase or } \\
\text { active pills ( } 6 \\
\text { days post- } \\
\text { ovulation). }\end{array}$ & $\begin{array}{l}\text { Saliva } \\
\text { hormon } \\
\text { e assays. } \\
\text { Ovulator } \\
\text { y phase } \\
\text { individua } \\
\text { Ily } \\
\text { determi } \\
\text { ned } \\
\text { using } \\
\text { ovulatio } \\
\mathrm{n} \\
\text { predicto } \\
\text { r kits. }\end{array}$ & $\begin{array}{l}\text { - Mental } \\
\text { rotation } \\
\text { - Verbal } \\
\text { fluency }\end{array}$ & $\begin{array}{l}\text { 1) Non-users performed better } \\
\text { on the mental rotation and } \\
\text { verbal fluency tasks compared to } \\
\text { OC users. No differences across } \\
\text { cycle phase. } \\
\text { 2) Third generation (androgenic) } \\
\text { OC users performed worse on } \\
\text { verbal fluency compared to new } \\
\text { generation (anti-androgenic) } \\
\text { users and non-users. } \\
\text { 3) Third generation OC users } \\
\text { performed worse on mental } \\
\text { rotation compared to non-users. }\end{array}$ \\
\hline $\begin{array}{l}\text { Hollow } \\
\text { ay, } \\
\text { Beck \& } \\
\text { Servati } \\
\text { us } \\
\text { (2011) }\end{array}$ & $\begin{array}{l}\text { University } \\
\text { students } \\
\text { (aged 18- } \\
23 \text { yrs) }\end{array}$ & $\begin{array}{l}\text { OC users } \\
\text { (monophasic } \\
n=7 \\
\text { triphasic } n=8) \\
\text { Follicular }(n=8) \\
\text { Luteal }(n=7) \\
\text { Total } n=15\end{array}$ & $\begin{array}{l}\text { Follicular, } \\
\text { days 4-11 } \\
(\mathrm{n}=13) \\
\text { Luteal, } \\
\text { days 19-26 } \\
(\mathrm{n}=14) \\
\text { Male } \\
\text { controls } \\
(\mathrm{n}=19)\end{array}$ & $\begin{array}{l}\text { All subjects } \\
\text { tested once. }\end{array}$ & $\begin{array}{l}\text { Menstru } \\
\text { al cycle } \\
\text { question } \\
\text {-naire. }\end{array}$ & $\begin{array}{l}\text { - Classically } \\
\text { conditione } \\
\text { d motor } \\
\text { (eye-blink) } \\
\text { response } \\
\text { (i.e. } \\
\text { associative } \\
\text { learning) } \\
\text { - Prepulse } \\
\text { inhibition }\end{array}$ & $\begin{array}{l}\text { 1) } 4 \text { group analysis (OC users, } \\
\text { follicular non-users, luteal non- } \\
\text { users, males): OC users acquired } \\
\text { the conditioned eye-blink } \\
\text { response quicker than males. } \\
\text { 2) } 2 \text { (OC use) x } 2 \text { (cycle phase) } \\
\text { analysis: OC users acquired eye- } \\
\text { blink response quicker than non- } \\
\text { users. }\end{array}$ \\
\hline
\end{tabular}




\begin{tabular}{|c|c|c|c|c|c|c|c|}
\hline & & & Total $n=46$ & & & (PPI) & $\begin{array}{l}\text { 3) } 4 \text { group analysis (OC users, } \\
\text { follicular non-users, luteal non- } \\
\text { users, males): under certain } \\
\text { stimulus conditions, PPI was } \\
\text { lower in males and OC users, } \\
\text { compared to female non-users. } \\
\text { Did not analyse OC users across } \\
\text { cycle phase or OC type. }\end{array}$ \\
\hline $\begin{array}{l}\text { Islam } \\
\text { et al. } \\
(2008)\end{array}$ & $\begin{array}{l}\text { University } \\
\text { students } \\
(21 \pm 4.2 \\
\text { yrs) }\end{array}$ & $\begin{array}{l}\text { OC users } \\
\text { (all monophasic } \\
\text { OCs) } \\
\text { Total } \mathbf{n = 1 6}\end{array}$ & $\begin{array}{l}\text { Women } \\
\text { with a } \\
\text { regular, } \\
\text { natural } \\
\text { cycle } \\
\text { Total } \mathbf{n}=\mathbf{1 2}\end{array}$ & $\begin{array}{l}\text { All subjects } \\
\text { tested twice, } \\
\text { during: } \\
\text { 1) early luteal } \\
\text { phase (1-4 } \\
\text { days after } \\
\text { ovulation or } \\
\text { active pill } \\
\text { days 13-16), } \\
\text { 2) early } \\
\text { follicular } \\
\text { phase (days } \\
\text { 4-7) }\end{array}$ & $\begin{array}{l}\text { Basal } \\
\text { body } \\
\text { temperatu } \\
\text { re and } \\
\text { blood } \\
\text { plasma } \\
\text { hormone } \\
\text { assays. }\end{array}$ & $\begin{array}{l}\text { - Verbal } \\
\text { learning } \\
\text { and } \\
\text { memory } \\
\text { - Object } \\
\text { memory } \\
\text { - Working } \\
\text { memory } \\
\text { - Verbal } \\
\text { fluency } \\
\text { - Mental } \\
\text { rotation } \\
\text { - Attention }\end{array}$ & $\begin{array}{l}\text { 1) No difference between } O C \\
\text { users and non-users on any } \\
\text { cognitive measure. } \\
\text { 2) Non-users had a greater rate } \\
\text { of learning during the early } \\
\text { follicular phase than the early } \\
\text { luteal phase on the verbal } \\
\text { learning and memory task. }\end{array}$ \\
\hline $\begin{array}{l}\text { McFad } \\
\text { den } \\
(2000)\end{array}$ & $\begin{array}{l}\text { Communi } \\
\text { ty } \\
\text { Individual } \\
\mathrm{s} \\
\text { ( } 21 \mathrm{yrs} \text { ) }\end{array}$ & $\begin{array}{l}\text { OC users } \\
\text { (all combined } \\
\text { OCs, } \\
57 \% \\
\text { monophasic) } \\
\text { Total } \mathbf{n}=\mathbf{5 7}\end{array}$ & $\begin{array}{l}\text { Mid-luteal, } \\
\text { days 16-26 } \\
(\mathrm{n}=86) \\
\text { Male } \\
\text { controls } \\
(\mathrm{n}=104) \\
\\
\text { Total } \\
\mathrm{n}=190\end{array}$ & $\begin{array}{l}\text { All subjects } \\
\text { tested once. } \\
\text { Phase at time } \\
\text { of testing for } \\
\text { OC users was } \\
\text { not recorded. }\end{array}$ & $\begin{array}{l}\text { Menstru } \\
\text { al cycle } \\
\text { question } \\
\text {-naire. }\end{array}$ & $\begin{array}{l}\text { - Spatial } \\
\text { ability }\end{array}$ & $\begin{array}{l}\text { 1) OC users performed } \\
\text { intermediate to males and mid- } \\
\text { luteal phase women, where } \\
\text { males had the best performance. } \\
\text { This reached significance for the } \\
\text { water level task but not the } \\
\text { mental rotation task. }\end{array}$ \\
\hline $\begin{array}{l}\text { Mihali } \\
\text { k et al. } \\
(2009)\end{array}$ & $\begin{array}{l}\text { University } \\
\text { students } \\
(21 \pm 1.7 \\
\text { yrs) }\end{array}$ & $\begin{array}{l}\text { OC users } \\
\text { (monophasic or } \\
\text { triphasic } \\
\text { combined OCs) } \\
\text { Total } \mathbf{n = 2 4}\end{array}$ & $\begin{array}{l}\text { Women } \\
\text { with a } \\
\text { regular, } \\
\text { natural } \\
\text { cycle } \\
\text { Total } \mathbf{n}=\mathbf{1 2}\end{array}$ & $\begin{array}{l}\text { All subjects } \\
\text { tested twice, } \\
\text { during: } \\
\text { 1) mid- } \\
\text { follicular } \\
\text { phase (3-5 } \\
\text { days after } \\
\text { menstruation } \\
\text { cessation), } \\
\text { 2) late luteal } \\
\text { phase (4-6 } \\
\text { days prior to } \\
\text { menstruation } \\
\text { ). }\end{array}$ & $\begin{array}{l}\text { Menstru } \\
\text { al cycle } \\
\text { question } \\
\text {-naire. }\end{array}$ & $\begin{array}{l}\text { - Verbal } \\
\text { memory } \\
\text { - Visual } \\
\text { memory } \\
\text { - Visual } \\
\text { motor } \\
\text { processing } \\
\text { speed }\end{array}$ & $\begin{array}{l}\text { 1) No difference between } O C \\
\text { users and non-users at either } \\
\text { time point on any cognitive } \\
\text { measure. }\end{array}$ \\
\hline $\begin{array}{l}\text { Morde } \\
\text { cai, } \\
\text { Rubin } \\
\text { \& Maki } \\
\text { (2008) }\end{array}$ & $\begin{array}{l}\text { Communi } \\
\text { ty } \\
\text { Individual } \\
\text { s } \\
(25 \pm 5.0 \\
\text { yrs) }\end{array}$ & $\begin{array}{l}\text { OC users } \\
\text { (all combined } \\
\text { OCs, monophasic } \\
n=8 \text {, } \\
\text { triphasic } n=12 \text { ) } \\
\text { Total } \mathbf{n}=\mathbf{2 0}\end{array}$ & $\begin{array}{l}\text { Women } \\
\text { with a } \\
\text { regular, } \\
\text { natural } \\
\text { cycle } \\
\text { Total } \mathbf{n}=16\end{array}$ & $\begin{array}{l}\text { All subjects } \\
\text { tested twice, } \\
\text { during: } \\
\text { 1) early } \\
\text { follicular } \\
\text { phase or } \\
\text { inactive pills } \\
\text { (days 2-4), }\end{array}$ & $\begin{array}{l}\text { Blood } \\
\text { serum } \\
\text { hormon } \\
\text { e assays. }\end{array}$ & $\begin{array}{l}\text { - Verbal } \\
\text { memory } \\
\text { - Verbal } \\
\text { fluency } \\
\text { - Visual } \\
\text { memory } \\
\text { - Mental }\end{array}$ & $\begin{array}{l}\text { 1) No group differences between } \\
\text { OC users and non-users. } \\
\text { 2) OC users performed better on } \\
\text { the verbal memory task during } \\
\text { the active pill phase compared to } \\
\text { the inactive pill phase. No } \\
\text { difference in non-users across } \\
\text { the cycle. }\end{array}$ \\
\hline
\end{tabular}




\begin{tabular}{|c|c|c|c|c|c|c|c|}
\hline & & & & $\begin{array}{l}\text { 2) mid-luteal } \\
\text { phase or } \\
\text { active pills } \\
\text { (days 20-22). }\end{array}$ & & $\begin{array}{l}\text { rotation } \\
\text { - Attention }\end{array}$ & $\begin{array}{l}\text { 3) No difference in any other } \\
\text { cognitive task across the cycle. }\end{array}$ \\
\hline $\begin{array}{l}\text { Nielsen } \\
\text { et al. } \\
\text { (2011) }\end{array}$ & $\begin{array}{l}\text { University } \\
\text { students } \\
\text { (aged 18- } \\
35 \text { yrs) }\end{array}$ & $\begin{array}{l}\text { OC users } \\
\text { (all combined } \\
\text { OCs, monophasic } \\
n=29 \text {, } \\
\text { triphasic } n=5 \text { ) } \\
\text { Total } n=34\end{array}$ & $\begin{array}{l}\text { Women } \\
\text { with a } \\
\text { regular, } \\
\text { natural } \\
\text { cycle } \\
\text { Total } \mathbf{n}=\mathbf{3 2}\end{array}$ & $\begin{array}{l}\text { All subjects } \\
\text { tested twice, } \\
\text { one week } \\
\text { apart. Cycle } \\
\text { phase at time } \\
\text { of testing is } \\
\text { unknown. }\end{array}$ & $\begin{array}{l}\text { Self- } \\
\text { report. }\end{array}$ & $\begin{array}{l}\text { - Emotional } \\
\text { memory } \\
\text { - Eye } \\
\text { fixation } \\
\text { (i.e. } \\
\text { attention) }\end{array}$ & $\begin{array}{l}\text { 1) No difference between OC } \\
\text { users and non-users on total } \\
\text { recall of the emotional memory } \\
\text { task. OC users had enhanced } \\
\text { memory for gist of the emotional } \\
\text { story, while non-users recalled } \\
\text { more details from the emotional } \\
\text { story. } \\
\text { 2) No difference between OC } \\
\text { users and non-users on } \\
\text { attention. }\end{array}$ \\
\hline $\begin{array}{c}\text { Rosenb } \\
\text { erg \& } \\
\text { Park } \\
\text { (2002) }\end{array}$ & $\begin{array}{l}\text { University } \\
\text { members } \\
(19 \pm 0.2 \\
\text { yrs) }\end{array}$ & $\begin{array}{l}\text { OC users } \\
\text { (non-triphasic } \\
\text { pills for } \\
>3 \text { months) } \\
\text { Total } n=10\end{array}$ & $\begin{array}{l}\text { Women } \\
\text { with a } \\
\text { regular, } \\
\text { natural } \\
\text { cycle } \\
\text { Total } \mathbf{n = 8}\end{array}$ & $\begin{array}{l}\text { All subjects } \\
\text { tested four } \\
\text { times: days } 1 \text {, } \\
7,14 \& 21 \text {. }\end{array}$ & $\begin{array}{l}\text { Basal } \\
\text { body } \\
\text { tempera } \\
\text { ture } \\
\text { measure } \\
\text { ment }\end{array}$ & $\begin{array}{l}\text { - Spatial } \\
\text { ability } \\
\text { - Verbal } \\
\text { working } \\
\text { memory }\end{array}$ & $\begin{array}{l}\text { 1) No difference in either task } \\
\text { between OC users and non- } \\
\text { users. } \\
\text { 2) No difference across the cycle } \\
\text { in OC users. Non-users } \\
\text { performed better on the verbal } \\
\text { memory task on days } 7 \& 14 \text {, } \\
\text { compared to days } 1 \& 21 \text {. }\end{array}$ \\
\hline $\begin{array}{l}\text { Vranic } \\
\& \\
\text { Hroma } \\
\text { tko } \\
(2008)\end{array}$ & $\begin{array}{l}\text { Communi } \\
\text { ty } \\
\text { Individual } \\
\text { s } \\
(21 \pm 1.4 \\
\text { yrs) }\end{array}$ & $\begin{array}{l}\text { OC users (all } \\
\text { triphasic) } \\
\text { Inactive pills } \\
\text { ( } n=14) \\
\text { Active pills } \\
(n=13) \\
\text { Total } \mathbf{n = 2 7}\end{array}$ & $\begin{array}{l}\text { Early } \\
\text { follicular, } \\
\text { days 1-7 } \\
\text { ( } n=29) \\
\text { Late } \\
\text { follicular } \\
\text { (3 days } \\
\text { before } \\
\text { ovulation) } \\
\text { or } \\
\text { mid-luteal } \\
\text { (1 wk } \\
\text { before } \\
\text { menstruati } \\
\text { on) ( } n=37 \text { ) } \\
\text { Total } n=66\end{array}$ & $\begin{array}{l}\text { All subjects } \\
\text { tested once. }\end{array}$ & $\begin{array}{l}\text { Menstru } \\
\text { al cycle } \\
\text { question } \\
\text {-naire. }\end{array}$ & $\begin{array}{l}\text { - Working } \\
\text { memory }\end{array}$ & $\begin{array}{l}\text { 1) No difference between OC } \\
\text { users and non-users. } \\
\text { 2) Women were more efficient in } \\
\text { solving a content-specific } \\
\text { working memory task during } \\
\text { high-hormone phases of the } \\
\text { cycle than during low hormone } \\
\text { phase, regardless of whether the } \\
\text { hormone phase was naturally- or } \\
\text { OC-induced. }\end{array}$ \\
\hline $\begin{array}{l}\text { Whart } \\
\text { on et } \\
\text { al. } \\
(2008)\end{array}$ & $\begin{array}{l}\text { University } \\
\text { members } \\
(19 \pm 1.5 \\
\text { yrs) }\end{array}$ & 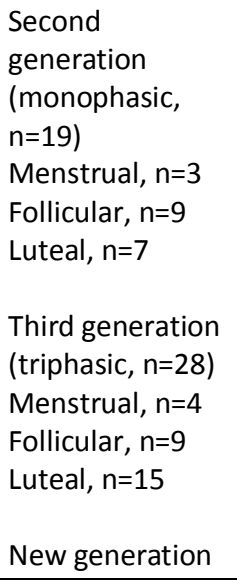 & $\begin{array}{l}\text { Menstrual, } \\
\text { days 1-5 } \\
(\mathrm{n}=13) \\
\text { Follicular, } \\
\text { days 6-14 } \\
(\mathrm{n}=22) \\
\text { Luteal, } \\
\text { days } 15-28 \\
\text { ( } \mathrm{n}=55) \\
\text { Total } \mathrm{n}=\mathbf{9 0}\end{array}$ & $\begin{array}{l}\text { All subjects } \\
\text { tested once. }\end{array}$ & $\begin{array}{l}\text { Menstru } \\
\text { al cycle } \\
\text { question } \\
\text {-naire. }\end{array}$ & $\begin{array}{l}\text { - Mental } \\
\text { rotation } \\
\text { - } \\
\text { Recognitio } \\
\text { n memory }\end{array}$ & $\begin{array}{l}\text { 1) All OC users vs. non-users: no } \\
\text { group differences. } \\
\text { 2) } 4 \text { group analysis (non-users vs } \\
3 \text { generations of OCs): non-users } \\
\text { outperformed new generation } \\
\text { (anti-androgenic) OC users on } \\
\text { mental rotation task. Also, trend } \\
\text { for second generation OC users } \\
\text { to outperform non-users. } \\
\text { 3) Menstrual cycle phase for } \\
\text { users and non-users: trend for } \\
\text { OC users to perform better on } \\
\text { mental rotation task during the } \\
\text { active pill phase than the inactive }\end{array}$ \\
\hline
\end{tabular}




\begin{tabular}{|l|l|l|l|l|l|}
\hline & $\begin{array}{l}\text { ('Yasmin', } \\
\text { monophasic, } \\
n=9) \\
\text { Menstrual, } n=2 \\
\text { Follicular, } n=5 \\
\text { Luteal, } n=2 \\
\text { Total } n=56\end{array}$ & & & & \\
\hline
\end{tabular}

